Chicago-Kent College of Law

Scholarly Commons @ IIT Chicago-Kent College of Law

All Faculty Scholarship

Faculty Scholarship

January 2007

\title{
Private Enforcement of Competition Law: A Comparative Perspective
}

David J. Gerber

IIT Chicago-Kent College of Law, dgerber@kentlaw.iit.edu

Follow this and additional works at: https://scholarship.kentlaw.iit.edu/fac_schol

Part of the Antitrust and Trade Regulation Commons, and the Comparative and Foreign Law

Commons

\section{Recommended Citation}

David J. Gerber, Private Enforcement of Competition Law: A Comparative Perspective, (2007).

Available at: https://scholarship.kentlaw.iit.edu/fac_schol/244

This Contribution to Book is brought to you for free and open access by the Faculty Scholarship at Scholarly Commons @ IIT Chicago-Kent College of Law. It has been accepted for inclusion in All Faculty Scholarship by an authorized administrator of Scholarly Commons @ IIT Chicago-Kent College of Law. For more information, please contact jwenger@kentlaw.iit.edu, ebarney@kentlaw.iit.edu. 


\section{The Enforcement of Competition Law in Europe}

Edited by

Thomas M.J. Möllers

and

Andreas Heinemann

With an essay by

David J. Gerber 
CAMBRIDGE UNIVERSITY PRESS

Cambridge, New York, Melbourne, Madrid, Cape Town, Singapore, São Paulo, Delhi

Cambridge University Press

The Edinburgh Building, Cambridge CB2 8RU, UK

Published in the United States of America by Cambridge University Press, New York

www.cambridge.org

Information on this title: www.cambridge.org/9780521881104

C Thomas J. Möllers and Andreas Heinemann 2007

This publication is in copyright. Subject to statutory exception and to the provisions of relevant collective licensing agreements, no reproduction of any part may take place without the written permission of Cambridge University Press.

First published 2007

Printed in the United Kingdom at the University Press, Cambridge

A catalogue record for this publication is available from the British Library

ISBN 978-0-521-88110-4 hardback

Cambridge University Press has no responsibility for the persistence or accuracy of URLs for external or third-party internet websites referred to in this book, and does not guarantee that any content on such websites is, or will remain, accurate or appropriate. 


\title{
B. Private enforcement of competition law: a comparative perspective
}

\author{
DAVID J. GERBER
}

Private enforcement has long been a central part of US antitrust law experience, while it has played minor roles or none at all in European competition law systems. This contrast is fundamental to understanding differences between European and US competition law and to assessing the potential consequences of increasing the role of private enforcement of competition law in Europe. It is also central to decisions about competition law development in much of the world, because in this respect most competition law systems in the world resemble European competition laws rather than US antitrust law. ${ }^{1}$

In this essay, I examine the private enforcement of competition law in the US and Europe against the backdrop of efforts in Europe to rely more heavily on private enforcement in the enforcement of its competition law. ${ }^{2}$ As part of its so-called 'modernization' efforts, which went into effect on May 1, 2004, the European Commission seeks to reduce reliance on administrative authorities and to encourage those harmed by restraints on competition to bring private law suits in national courts. ${ }^{3}$ There is, however, widespread uncertainty about the prospects

${ }^{1}$ I use the term 'competition law' here to refer to general legal regimes that impose sanctions on conduct because such conduct restrains competition. The term 'antitrust" is often also applied to this type of legal regime, particularly in reference to the competition law of the United States.

2 Although the Commission's modernization plans call for increased reliance on private enforcement, some question this objective. See, e.g., W. Wils, Should Private Antitrust Enforcement be Encouraged in Europe? (2003) 26 World Competition 473.

3 Council Regulation (EC) No. 1/2003 of December 16, 2002 on the implementation of the rules on competition laid down in articles 81 and 82 of the Treaty [2003] OJ L 1/l. For the early development of this project, see David J. Gerber, Law and Competition in Twentieth Century Europe: Protecting Prometheus (1998), p. 392-401. 
for successfully incorporating private litigation into European competition law systems. There is also uncertainty about which, if any, measures should be taken to enhance acceptance of private enforcement. ${ }^{4}$

In assessing these issues, a comparative perspective can be of much value. It can provide a basis - perhaps the only sound basis - for making informed decisions. US experience with private enforcement is far more extensive than that of any other country, and thus our focus here will be on that experience and its potential relevance for decisions about private enforcement in Europe. In order for such a comparison to be of value, however, it must go beyond the juxtaposition of rules and institutions and ask what the operational differences between the systems are and how they are likely to affect the operation of private enforcement mechanisms.

While this type of comparative analysis can be of significant value in assessing the situation in Europe, we cannot expect to draw firm predictions or certain prescriptions from it; differences between US and European competition law institutions and experience are too great for that. We can, however, gain insight into both the likely consequences of particular implementation decisions and the kinds of measures, if any, that are likely to be useful in facilitating the development of private enforcement in Europe.

A central claim of this essay is that private enforcement of competition law is more than merely a specific way of enforcing competition law. It engenders, and is interwoven with, distinct patterns of thought, institutional relationships, styles of argumentation, distributions of power and social and economic structures. Understanding this imbeddedness is thus critical to assessing the potential impact of private enforcement on the development of competition law in Europe. ${ }^{5}$

The essay is part of the introductory material to a book on private enforcement issues in Europe that includes a series of national reports. As such, it is intended to provide a frame of reference for those reports -

${ }^{4}$ For extended discussion of these issues, see, e.g., C.D. Ehlermann and I. Atanasiu (eds.), European Competition Law Annual 2001: Effective Private Enforcement of EC Antitrust Law (2003); Clifford A. Jones, Private Enforcement of Antitrust Law in the EU, UK and USA (1999); W. Wils, The Optimal Enforcement of EC Antitrust Law: Essays in Law and Economics (2002).

5 This essay focuses on issues relevant to the introduction of private enforcement into European competition law systems, but its potential relevance is far broader. As noted above, competition law systems around the world tend to be closer to the European 'model' in this regard than they are to the US system, and thus much of the analysis here is applicable also to those systems. 
a means of relating them to each other and to competition law experience in the US.

The comparison has three components. The first focuses on US experience with private enforcement. I look at how private enforcement was introduced there, what roles it has played, and what factors have contributed to its continued prominence. I then turn to European competition law experience, highlighting the role and significance of administrative decision making in European competition law experience. The reliance on administrative direction of competition law has created a set of assumptions and institutional arrangements relating to competition law that differ significantly from those that have been generated in the US. The third part analyses the differences between these two experiences and assesses the relevance of European competition law systems and the lessons (or lack thereof) that US experience provides for pursuing the goal of increased private enforcement in Europe. 


\section{Private enforcement in US antitrust law}

Private enforcement has been an integral part of US antitrust law experience since the enactment of the first antitrust law statute in $1890{ }^{1}{ }^{1}$ It has long been seen as a natural and even indispensable means of enforcing antitrust law. It has also shaped the operations of the system, the development of the substantive law, and the attitudes, capacities and roles of the individuals who participate in the system.

\section{From the beginning: neither choice, nor issue}

The decision to make private enforcement a key component of US antitrust law was not made in the context of a careful choice among alternatives. When the Sherman Act was enacted, ${ }^{2}$ private enforcement was merely assumed to be a primary means of enforcing the statute. The legislation was understood as a tool for increasing the enforcement of existing common law principles by creating administrative support and by generating access to the federal courts for private litigants. It 'codified' existing case law and gave the federal government and the federal courts authority to apply those substantive principles. ${ }^{3}$ The decision was not based on a careful study of alternatives, because no alternatives were apparent. There were no comparable systems in the world, and thus there was no foreign experience to evaluate. From the beginning, therefore, there has been little perceived need to justify or examine private law enforcement. Few have even called into question its predominant role in the system. ${ }^{4}$

\section{Private enforcement in the evolution of the US antitrust system}

The basic institutional structure of the US antitrust system has changed little since its inception. ${ }^{5}$ The same vaguely worded statute (the

${ }^{1}$ This essay refers exclusively to enforcement of the federal antitrust laws. This is by far the most important area of experience with private enforcement, although there is occasional litigation involving enforcement of state antitrust laws.

215 U.S.C. $\S 1$ (2001).

3 'Codification' in US legal terminology refers to the act of legislation, and does not imply the creation or development of 'codes' as known in civil law systems.

${ }^{4}$ This does not mean, of course, that there have not been discussions on occasion about its value, but the issue of eliminating private enforcement has not been seriously considered.

${ }^{5}$ For leading discussions of the development of US antitrust laws, see H. Hovenkamp and G. Hosking, Enterprise and American Law, 1836-1937 (1991); W. Kovacic and C. Shapiro, Antitrust Policy: A Century of Economic and Legal Thinking, (2000) 14 J. Econ. Perspectives 43; 
Sherman Act) is still its main text, and private enforcement has remained an important part of the system throughout its development. Private antitrust actions have not always been numerous, but they have generally been a serious option, and at times they have played more prominent roles than has public enforcement.

Specific elements, doctrines, and institutions of the system have evolved, however, and some of those changes are important for assessing the current role of private enforcement. We can identify three phases in this development. Private enforcement has played a role in each, but its roles and impact have varied over time.

During the first phase of development, which lasted until the Second World War, the role of antitrust law was often uncertain. At times there was significant debate about its effectiveness, and the courts often wrestled with the application of its vague statutory provisions. Both public and private forms of enforcement were episodic. There were periods during which the courts seemed hospitable to antitrust suits, and this usually led to increased litigation, but there were other periods during which there was little litigation, private or public. On several occasions there was increased political force behind public enforcement, leading administrative authorities to 'push' the courts and to encourage private litigation. Towards the end of the New Deal in the 1930s there were renewed efforts to reinvigorate antitrust law enforcement, but it was not until after the Second World War that the role and significance of the antitrust system expanded rapidly.

The second phase, which lasted for some three decades after the close of the Second World War, saw antitrust achieve exceptional levels of influence and importance. During this period, there was some new auxiliary legislation, but the primary factors in the expanded role of antitrust were the willingness of courts to expand interpretations of existing statutes and the willingness of law enforcement personnel to pursue such developments. These developments reflected shifting social and political values as well as an international situation which deterred investment in US market and encouraged US business firms to expand their activities internationally. With the domestic market largely protected from foreign economic pressures and international competition, antitrust laws were seen as a means of responding to the growing size and power of US domestic corporations. 
Increased judicial support for antitrust doctrines led to both increased public enforcement efforts and increased incentives for private litigation. The two were related: the likelihood of success in the courts encouraged greater public enforcement efforts, and increased public successes, in turn, combined with greater publicity and the perceived importance of antitrust law to induce more private litigation. As a result of these factors, antitrust law became a major factor in much business decision making. By the late 1960s, it seemed to some that plaintiffs seldom lost antitrust litigation.

In the 1970s, however, economic and political conditions in the US and in the world changed rapidly. As the US economy was exposed to increased international competition, judges and enforcement officials became more willing to assume that the competitive forces of the market would deter anti-competitive conduct and more reluctant to 'interfere' with the operation of US enterprises by imposing on them conduct obligations that many of their competitors did not face in other markets.

This change in perspective was associated with a radical reorientation of antitrust thinking that is often called the law and economics 'revolution'. ${ }^{6}$ It was initially generated by a group of legal academics who sought to base antitrust doctrine on a particular form of economic analysis known as price theory. ${ }^{7}$ They scrutinized the case law of the immediately preceding period and attacked it for its lack of rigour in economic analysis. This perspective quickly gained favour within US antitrust law. It was ideologically consistent with the laissez-faire ideology of Ronald Reagan, and, as a result, it became the framework for public enforcement. Moreover, it was congenial to many of the federal judges that President Reagan appointed.

As a result, the law and economics approach to antitrust law began to reshape the meaning of the antitrust laws, replacing the prevailing mixture of case law analysis and social and political values with analytical tools based on a specific set of economic principles. This set of ideas came to dominate antitrust thinking during the 1980s and remains a form of orthodoxy. For private enforcement, it has meant significantly

6 See R.A. Posner, Economic Analysis of Law (5th edn 1998). For discussion of this transition, see E.M. Fox and L.A. Sullivan, Antitrust - Retrospective and Prospective: Where are we coming from? Where are we going? (1987) 62 N.Y.U.L. Rev. 936.

${ }^{7}$ For comparison of competition law thought and scholarship in the US and Europe, see D.J. Gerber, Competition, in Oxford Handbook of Legal Studies 510 (2003). 
more obstacles to winning private antitrust suits and thus significantly less litigation.

\section{Operational features of the US antitrust systems}

In the US antitrust system, private enforcement has several features that are important for assessing its operation. Some are specific to antitrust law, while others are provided by the general procedural system that must be used in antitrust enforcement.

One is the concept of a 'private attorney general'. In general usage, the term 'attorney general' refers to the public prosecutor - i.e., the person who decides whether a criminal case should be submitted to the courts. Here, however, it refers to the use of private litigation as a means of bringing potential violations into courts and therefore assisting public authorities in their enforcement role. In this context, the private plaintiff plays a public role: she is cast as a surrogate for the government. In the US, public enforcement has long been assumed to be inadequate to achieve effective enforcement, and thus private litigation is used as a means of public enforcement. By giving private litigants incentives to bring civil suits, it is thought, government can more efficiently and effectively achieve compliance with the antitrust laws. The most important of these incentives is the availability of treble (i.e., triple) damages for violations of the antitrust laws. Where a plaintiff is successful in a law suit for compensation, the compensation awarded may be increased to three times the actual amount of harm caused by the antitrust law violation. This provision was part of the original Sherman Act and was specifically included as an incentive to private suits and an antidote to excessive reliance on public enforcement.

In addition to provisions such as this that are specifically aimed at encouraging private litigation, the general procedural rules of the US system contain other features that have the same effect. One is 'punitive damages' (or 'penalty' damages). In considering the amount of compensation to be awarded by a court for harm caused by a violation of the law, judges (and juries, where they are present) are often entitled to increase the compensation beyond the amount of harm caused in order to punish the offender and deter similar conduct in the future. Another potential incentive is provided by the US discovery system. Under that system, litigants in private litigation acquire extensive rights to request and, often, to compel the 'production' (or presentation) of information from other parties and sometimes even from others who are not parties 
to the litigation. Private litigation in the US federal courts requires litigants to make available to opposing litigants all information requested by them that can reasonably be expected to lead to evidence that is 'admissible' (i.e., that can be presented in court). This often enables litigants to acquire large amounts of information which they can use in the litigation itself, but which they can also use for other strategic purposes.

\section{Contexts of private enforcement}

The effectiveness of private enforcement depends on many factors other than the legal provisions relating to the private enforcement mechanism itself. It cannot be meaningfully assessed without taking into account its relationship to the rest of the system, because the context in which it operates shapes its operations and conditions its role.

Private enforcement is only one means of enforcement, and thus its relationship to other means of enforcement is central to its operation. In the US system, two agencies of the Federal government are authorized to enforce the competition laws. One is the United States Justice Department, which is part of the executive branch of government and subject, therefore, to political control. The Justice Department must operate through the courts. This means that it cannot issue enforce orders directly, but must bring a lawsuit in the regular courts to effectuate its enforcement objectives. Moreover, when it pursues litigation in court, it is basically subject to the general procedures of the courts. It may bring either civil or criminal actions, depending on the gravity of the conduct and other factors such as the intent of the defendants. The other enforcement agency is the Federal Trade Commission. It operates as an independent agency, but it depends for funding on Congress, and it is thus subject to political pressures. In some eras, it has played significant roles in antitrust enforcement; in others, its role has been marginal. It may issue orders directly to private decision makers, but its orders are reviewable by the regular courts.

Private enforcement operates parallel to these administrative enforcement mechanisms, applying the same substantive legal principles, using the same court system and, to a large extent, the same procedural rules and institutions. The private enforcement mechanism thus interacts with public enforcement at many points. Where public agencies decide not to pursue certain categories of cases, for example, this often tends to reduce the perceived importance of the claims. This 
often tends, in turn, to reduce judicial receptiveness to such claims and to deter potential private enforcement litigation.

The structure and characteristics of the legal profession are another important factor in the operation of the private enforcement mechanism. Private enforcement can be effective only if there are significant numbers of private legal professionals who are willing and able to pursue these claims aggressively. The organization, political position, and professional characteristics of private legal professionals - i.e. 'lawyers' - influence the opportunities for private litigation that are available within the system and the incentives for utilizing those opportunities. In the US, this group of legal professionals is large and politically powerful. It is organized in ways that encourage litigation generally and that also facilitate expensive private litigation. This includes, for example, common use of contingent fees in antitrust litigation, ${ }^{8}$ employment of large numbers of 'associate' attorneys (junior lawyers) who can work in large teams and can be readily mobilized for large group efforts and 'paralegals' (employees who have minimal legal training, but who are permitted to perform certain kinds of data gathering and other tasks). Aggressive litigation techniques are also part of the culture of the profession.

Finally, the societal context plays a role. In the US, litigation is common and culturally approved, particularly among and between businesses, and high fees for litigation are generally accepted. Moreover, competition as a process is highly valued. It is a cultural symbol with significant political support and attraction. Not surprisingly, therefore, there is a long tradition of antitrust litigation.

\section{The impact of private enforcement on system operations}

Just as the systemic context influences the operation of private enforcement mechanisms, so private enforcement influences other elements of the system. Because private enforcement is deeply imbedded in the US system, there is no reliable way to specify cause-effect relationships here, but we can identify associations and interrelationships between private enforcement and other elements of the system.

Private enforcement has perhaps its most direct effect on public enforcement. Where private antitrust litigation is common, as in the

${ }^{8}$ Contingent fees (often known in civil law systems under the rubric pacta de quota litis) provide that attorneys for the plaintiff will receive a percentage of the amount, if any, recovered in the litigation. If the plaintiff loses, the lawyer receives no compensation. 
US, the capacity of public officials to influence the development of the antitrust system is limited. Public institutions in the US can influence the direction of law in specific areas, but private litigation decisions are driven by private considerations and depend on private assessments of the potential value of litigation in relation to its costs. This may have little or nothing to do with the strategies of public enforcement officials, and thus efforts by public officials to develop particular types of arguments or focus on particular types of cases are less important than in systems where the only competition law enforcement efforts are those of an administrative body and, perhaps, a reviewing court.

This also means that the regular courts tend to a play a role in the development and operation of the system that is more central than it is in systems where courts merely review administrative decisions. In the US, the courts do not play the limited role of constraining competition authorities. They are instead the centre of the system - the arbiters of what the law is and the primary factors in determining the development of the law. Court decisions and the case law interactions among courts are the reference point for both public enforcers and private lawyers in making competition law decisions.

Not only are courts more important in the US system, but so are private attorneys. Their initiative and advice determine whether private litigation takes place, and thus they channel the flow of litigation. They also determine the strategies and arguments that are used in litigation, and thus they influence the terms of discussion and play a major role in influencing substantive law development. The potential for earning significant fees provides powerful incentives for private attorneys to learn about antitrust law and to pursue private grievances in the courts.

This structure of institutions and incentives means that the goals and concepts of competition law tend to be loosely defined. Since no competition authority directs the development of the law, and many courts may be involved, there are many voices involved in articulating goals and defining concepts. In the US system at least, this has led to frequent uncertainty about the goals of competition law and, often, little coherence and consistency in the definition and development of concepts.

The prominence of private enforcement also has a significant impact on awareness and perceptions of antitrust law and on attitudes toward it. It tends to heighten awareness of the antitrust laws not only among lawyers and business leaders, but also within the general public. Litigation in which business firms are pitted against each other also tends to make interesting reading and to be reported in the general 
press, especially where large sums of money or well-known businesses are involved. This awareness, in turn, increases the likelihood that potential private litigants will at least consider the possibility of private litigation. Depending on the content of the media exposure, however, it may lead to more or less confidence in predictions of the costs and benefits of private litigation.

\section{Private enforcement and the US antitrust system}

This brief overview of private enforcement in the US antitrust system reveals a component of the system that has been part of it from the beginning and that is accepted as a normal, effective, indeed almost indispensable part of that system. There is little need to justify it, and it is supported by many of the basic assumptions and institutions of the legal system and the society in which it operates. 


\section{Competition law in Europe: administrative centrality}

Competition law is enforced very differently in Europe. There, competition law has developed primarily as an administrative, public law issue. Private enforcement has played only marginal roles, and only in a few systems. In this section we look at that very different experience and the competition law dynamics that it has created. ${ }^{1}$

\section{National experience}

In Europe, competition law was originally conceived as an administrative tool, a means for the state to intervene in market processes in order to achieve public goals. These ideas were first articulated in the 1890s in Vienna, where a group of administrators and scholars who were part of a small educational elite began to explore the idea of using law to protect the process of competition. Imbued with the values of classical liberalism and aware of the new theoretical developments in understanding the economic process that were emanating from the Austrian school of marginal utility economics, they began to investigate whether the two strands of classical liberalism (economic freedom as a value and law as a protector of rights) could be used together. ${ }^{2}$

The proposal that emanated from this project understood competition law as a means by which bureaucrats could intervene to reduce harms to competition (and perhaps enhance their own influence). This approach had two important advantages for the administrative elite: it gave them influence, and it could be implemented with minimal cost either economic or political. Moreover, there was no obvious alternative to this approach. There was no pre-existing set of substantive principles that could be merely applied by courts, as was the case in the US. ${ }^{3}$ The proposal almost became law in Austria, but in the end it was the victim of the political disruptions of the late 1890s.

The basic ideas were further developed, however, in Germany. They there attracted support from social democratic leaders and representatives of small and medium-sized enterprises, who saw competition law

1 This section is based primarily on my detailed study of the development of competition law in Europe. See D. J. Gerber, Law and Competition (note 3 above).

${ }^{2}$ I recount this development in detail in D.J. Gerber, The Origins of the European Competition Law Tradition in Fin-de-Siecle Austria (1992) 36 Am. J. Leg. Hist. 405, and in D. J. Gerber, Law and Competition (note 3 above), at 43-68.

3 There were Roman law provisions that formed part of the jus commune, but they were not considered relevant. See D. J. Gerber (note 3 above), at 34-7. 
as a means of protecting their interests against the power of large industrial firms and cartels. Not until after the First World War, however, was a competition law enacted. In the midst of the battle against hyperinflation in 1923, legislation was introduced that followed the administrative model. Although enforced with limited effect, it received attention in other parts of Europe. By the late 1920s this administrative model was being widely discussed in Europe, and additional statutes based on it were enacted. ${ }^{4}$

After the Great Depression and the Second World War, this model again began to spread. Throughout Europe, there was an effort to find new economic and political forms that would generate wealth and jobs and, at least as importantly, avoid the catastrophes of the first half of the century. Competition law ideas were sometimes included in those plans, but there was seldom strong political support for them, and the statutes that were enacted often remained without significant implementation.

In Germany, however, a new element was added that led to a temporary divergence between German developments and those in other European systems. ${ }^{5}$ The German path was heavily influenced by what was originally an 'underground' intellectual movement during the Nazi period called ordoliberalism (or the 'Freiburg school' of law and economics). During the 1930s a group of lawyers and economists began to explore systematically the possibility of using law to protect the process of competition and thus prevent both the debacle of the Weimar period too little control of economic power - and the calamity of Nazism - too much control of social life by the state. They sought a means of protecting economic liberty and competition from both the state and private accumulations of power. The result was a highly refined conception of how law could be used to accomplish those objectives, and competition law was at its centre.

The central idea was that a polity's choice of an economic order should be understood as an 'economic constitution'. They advocated an order based on competition and economic freedom and argued that legal processes should be used to protect this economic constitution in essentially the same ways that law is used to protect the political constitution. Accordingly, decisions relating to the economic constitution

${ }^{4}$ For discussion, see ibid. at 153-162.

${ }^{5}$ For discussion, see D. J. Gerber, Constitutionalizing the Economy: German Neo-liberalism, Competition Law and the 'New Europe' (1994) 41 Am. J. Comp. L. 25. 
should be made according to judicial procedures! They should represent legal principles and be applied according to legal methods. Competition law was seen as the central tool for protecting this economic constitution, and thus it was to be implemented by the application of juridical principles rather than pursuant to administrative discretion.

In 1957, Germany enacted the first 'modern' competition law in Europe, the Law against Restraints of Competition (GWB). ${ }^{6}$ Although modified several times since then, its basic principles remain in effect. While relying primarily on administrative mechanisms to enforce competition law principles, the German system is understood as an essentially 'juridical' system in the sense that decisions are generally to be made according to well-developed judicial methods and procedures. The Federal Cartel Office (FCO) is the central institution in the system, but the statute also provides for review by the regular courts of FCO decisions. As modified, it also allows for private enforcement in certain kinds of cases.

In the rest of Europe, competition law remained almost exclusively 'administrative' for several decades after the Second World War, with no private suits and minimal involvement by the regular courts. The decisions of administrators were typically subject to legal control only for violation of administrative law principles.

As these systems have developed in importance, however, they have often modified their reliance on administrative decision making. Governments have increasingly restructured competition law decisionmaking, moving from almost total reliance on administrative discretion and policy judgment to a more central role for the methodologically grounded application of legal principles. Accordingly, for example, administrative decision making has been subjected to increasingly extensive review by courts. At the same time, administrators have been given increasingly powerful tools for combating competitive restraints.

\section{Competition law in the European Union}

A key factor in this move toward a more 'juridical' conception of competition law has been the process of European unification and the development of a highly sophisticated competition law within the European Union. The Rome Treaty that created the European

\footnotetext{
${ }^{6}$ Gesetz gegen Wettbewerbsbeschränkungen, 1957 Bundesgesetzblatt [BGB1] I 1081 (July 27,
} 1957). 
Economic Community in 1957 contained basic provisions concerning the protection of competition, and these were gradually developed into a system in which both administrative and judicial decision making play important roles. ${ }^{7}$

This development has frequently reflected significant German influence, particularly in its early years. Germany developed competition law earlier than other European systems, and German competition law has been consistently considered the best developed and most effectively enforced system in Europe. As a result, European Union developments have often drawn on German experience. Perhaps the most important element of that influence has been emphasis on a juridical conception of competition law rather than a merely administrative one.

From the early years of the evolution of the European Community, competition law has been a central component of its legal system. It has been used to break down barriers to trade and establish the conditions for positive economic development. The European Commission and the European Court of Justice have often used it to move the process of integration forward, especially during periods when the political impetus was weak. Although the Community competition law system contains strong administrative elements, it is imbedded in a juridical framework in which the two European Community courts play a central role.

EU competition law has been enforced almost exclusively by the European Commission. In interpreting and applying the European treaties and the secondary legislation of the European Union, the Commission can order the imposition of fines and prohibit cartels and other conduct such as mergers. The two European courts can review Commission actions to determine whether they are in conformity with the treaty and whether proper procedures have been followed.

Throughout this development private enforcement action has been non-existent or marginal. Originally, it was not even available under EU law. In the 1970s, legal barriers to private actions within European community law were removed, but such actions have remained rare. In the 1990s, the Commission took steps to encourage private enforcement, but they have had little effect. Those who consider themselves harmed by anti-competitive conduct continue to prefer to appeal to public enforcement authorities and to avoid filing private actions.

${ }^{7}$ For discussion, see Gerber, Law and Competition in Twentieth Century Europe (note 3 above), at 334-391. 
The so-called 'modernization' of EU competition law will change this system in fundamental ways. According to plans adopted in December 2002, and in effect since May 2004, national competition authorities and national courts will become the primary mechanisms for enforcing EU competition law. These reforms were designed to respond to the enlargement of the EU from fifteen to twenty-five members by reducing reliance on the Commission and increasing the role of private enforcement actions in local courts. They are the primary impetus for the widespread interest in private enforcement in Europe today.

\section{Administrative centrality and its implications}

This brief sketch of competition law in Europe reveals a system that has relied almost exclusively on public initiative and public decision making throughout its development. At both the national and European levels, competition authorities apply competition laws and control the development of the law. Private initiative and private enforcement play minimal roles at best. It has been alien to European competition law experience - in both practice and theory.

This shapes the operation of European competition law systems in many ways. For example, it structures the roles of competition authorities and their relationships with courts, the public and private legal practitioners. It means that those authorities have extensive power to control the development of the law in the area, subject only to the often limited constraints that reviewing courts may impose. Because of the lack of private enforcement opportunities, the competition authorities can focus attention on particular types of conduct and particular lines of argument. In effect, they can set the agenda for competition law. Assuming adequate political support, this in itself ensures that those authorities are in a powerful position when dealing with business entities.

In this situation, relationships with the courts tend to be narrow - in both scope and substance. ${ }^{8}$ They tend to be narrow in substance, because the courts can only approve or disapprove of the competition authority's decisions. They do not have a variety of opportunities and levels on which they can influence competition law outcomes and development. Its scope is narrow, because the relationship is typically

${ }^{8}$ For discussion of recent issues in this relationship, see D. J. Gerber, Courts as Economic Experts in European Merger Law, in 2003 Fordham Corporate Law Institute (2004), p. 475 et seq. 
limited to one agency and one or two appellate courts. In practice, it is even narrower, because it usually involves only a few judges who sit in the competition law chambers of the reviewing courts. This means that there is little awareness of competition law issues among most judges. The narrowness of the relationship focuses the attention of administrators, business leaders and, often, politicians on those few judges. This can facilitate the development of sound knowledge of competition law among these few judges, but it also has other types of effects. In some systems, for example, it may encourage efforts by politicians to control the competition authority by influencing the reviewing judges. It can also create a competitive relationship between the few judges involved and the leaders of the competition authority that may lead to decisions that are influenced by personal considerations.

This means, in turn, that private competition lawyers in these systems are defence lawyers and advisors, not plaintiffs' lawyers, as they frequently are in the US. Where there is no tradition or practice of commencing litigation against other firms for competition law violations, the mentality of lawyers centres on defence, in general, and defence against the decisions of a small number of officials in the competition authority. It means that the focus of lawyers is on predicting what the competition authority will do and developing means of influencing its decisions. Lawyers tend to pay far less attention to courts than is the case in the US, because the courts typically play a far more peripheral role in enforcement. At an even more fundamental level, administrative centrality shapes images of competition law - not only among judges, lawyers and administrators, but also among business decision makers and the general public. Competition law tends to be seen as government regulation. It is usually taught in law faculties as part of administrative law and conceptualized and enforced as part of administrative law. It is not a tool in the hands of businesses, but part of the administrative apparatus. As such, it is sometimes met with the resistance and even hostility that in some countries is directed toward government regulation generally. 


\section{Incorporating private enforcement into European competition law: comparative perspectives}

A comparison of US competition law and experience with European competition law and experience allows us to identify some of the effects that introducing and/or expanding private enforcement in Europe are likely to have. It also helps to identify factors that might influence the prospects for increased reliance on private enforcement in Europe.

The process of incorporating private enforcement into European competition law systems involves the introduction of an alien element into those systems. Many factors will determine the extent to which the newly created opportunities for private enforcement will actually be used and how rapidly any increase in usage will occur. For purposes of the following comments, I will assume that private enforcement of EU competition law will increase significantly as a result of the modernization reforms. Significant increases may, however, take several years perhaps a decade or more.

\section{Public enforcement}

The most direct impact is likely to be on public enforcement. European competition law systems have relied primarily on administrative decisionmaking since their inceptions. Government officials have played the central role in those systems, and administrative decision making and initiative have shaped their operation and evolution. A significant role for private enforcement is likely to have profound effects on this administrative orientation. It will mean that administrators no longer control the operation and development of competition law. Private law suits will be filed in pursuit of private interests, and these will not necessarily coincide with the public (or private) interests of administrators. Private lawyers will decide what kinds of arguments to make in these cases - with little or no regard to the arguments that administrators would have made. And courts that make decisions in these cases will influence legal development and effectiveness as much or more than administrators.

This will diminish the status of administrators, at least in some ways and in some contexts. The centrality of administrative decision making gives status to those who make administrative decisions, and eliminating or reducing administrative centrality will diminish that status accordingly. Assuming all other factors remain constant, this is likely, in turn, to make it more difficult to attract and maintain top-level 
administrators. To the extent that administrators increasingly think of their roles as preparation for careers outside competition law agencies, this also affects their incentives, and it may influence their decisions.

Other factors will, of course, condition the impact of this reduction in status. Administrative law traditions and operations differ significantly between the United States and Europe as well as within Europe, and thus generalization is dangerous. For example, the status of administrators in many countries in Europe tends to be significantly higher than their status in the US, and this may tend to counteract the potential effects of increased privatization.

Finally, the reduced control of competition law by administrators may influence the roles that competition authorities play. For example, in Europe such authorities have often played constructive and educational roles rather than merely enforcement roles. They have viewed the construction of markets and the education of business decision makers and consumers as important tasks, whereas this type of activity has generally been comparatively secondary in the US. To the extent that a significant role for private enforcement reduces the status of administrators and diminishes their control over the competition law agenda, it may impede both the incentives for administrators to play these roles and their capacity to perform them effectively. Where the voice of administrators within a competition law system is not the single or at least dominant voice, businesses have less incentive to follow the 'advice' of administrators and to value cooperative efforts with those administrators.

\section{Judges}

Increased private enforcement may also alter the role of judges in competition law systems. As noted above, in an administrative model, few judges deal with competition law issues, and their roles are typically limited. In the context of widespread private enforcement, however, many judges will be required to deal with competition law issues, and their roles will be more complex. They will not only have to review the decisions of an administrative agency, but they will also have to resolve private conflicts in which large sums of money are often involved. This will increase public and political attention to those courts and heighten pressures on them.

Moreover, courts are likely to become more important relative to administrative authorities. They tend to become the common reference points for the operation of the system. All - administrators as well as 
private attorneys and business decision makers - will increasingly focus on court decisions rather than administrative decisions in assessing their legal positions. This may not always mean increased status for judges, however, because many judges may be inadequately trained to deal competently with competition law cases, and thus a greater role in the system may lead to conflict and controversy over the training of judges.

\section{Private practitioners}

The roles of private practitioners and company advisers are also likely to change. At the very least, the possibility of private litigation adds a new dimension to those roles. Assessment of antitrust risk becomes more complex. No longer is it solely or even principally a matter of predicting what a competition authority is likely to do. Instead it requires assessing the likelihood of suit by competitors, suppliers, purchasers and others, and it requires attention to new issues of jurisdiction, evidence production, and tactical planning. Moreover, private practitioners will become plaintiffs' attorneys as well as defence attorneys. They will have to consider whether to advise clients to pursue private claims and assess the implications that such litigation will have on current practices such as hiring new legal professionals and billing clients.

\section{Goals and concepts}

The goals and concepts of competition law are likely to become both less clear and less coherent. Private enforcement changes the 'voice' of competition law. Rather than having one administrative office and, perhaps, one or two courts using concepts and articulating and interpreting goals and norms, private enforcement is likely to mean that many voices will use concepts and participate in the process of defining the goals of the system. This is likely to lead to less consistency in conceptual usage and less clarity in the articulation of goals.

\section{Perceptions and attitudes}

Finally, perceptions and attitudes among businesses and consumers are also likely to change. The possibility that competition law can be useful to many businesses as well as to consumers and consumer groups creates incentives for them to learn more about it. This, in turn, also means that the potential sources of legal challenges increase, and the need to engage in compliance and other defensive strategies to reduce the risk of legal challenge grows. Clients need to be made aware of these 
expanded possibilities. In general, awareness of competition law norms and procedures is likely to increase accordingly. As private enforcement increases, competition law will increasingly be seen as a tool for private interests as well as a public legal regime. Private enforcement contributes to the perception that competition law is an accessible, useful part of the legal system. For better or worse, it will no longer just represent state 'regulation'. 


\section{Concluding comments}

As we have seen, private enforcement of competition law is largely alien to European competition law experience and to current European competition law systems. This has two important consequences for efforts to expand its role. First, it means that there is likely to be systemic resistance to such efforts. Institutional interests, patterns of thought, and the expectations of both public and private decision makers may, for example, create obstacles to the success of private enforcement efforts. Second, as with the introduction of any alien element into any system, it is likely to create new and unforeseen conflicts with existing ways of operating.

Where decision makers understand the relationship between private enforcement mechanisms and the current system and also recognize the potential obstacles that differences between them can create for private enforcement, they can take steps to deal with those obstacles. Moreover, the sooner they anticipate the kinds of consequences that private enforcement can have on the current system, the greater the likelihood that they can adjust the two enforcement mechanisms to function effectively together.

US experience can be of value in identifying the factors that are likely to influence the development of private enforcement mechanisms within Europe and the consequences those developments will have on the operation of European competition law systems. The value of US experience for these purposes depends, however, on effective comparison of US experience with its European analogues. As we have seen, effective comparison cannot be limited to discussion of rules and cases, but must view private enforcement as a specific mode of operation that involves institutions, power relationships and ways of thinking. Where this comparison is careful and informed, its value can be great. To the extent that it is superficial and haphazard, it will be at best valueless and at worse misleading and harmful.

Private enforcement of competition law in Europe is likely to develop along lines that are in some ways quite different from US experience. The institutions that have now acquired status within European competition law systems will continue to operate, and the ways of thinking, valuing and operating that have developed over the last half century will continue to have influence. The development of private enforcement is likely to depend in large part on careful adaptation to this European environment. Moreover, policy decisions relating to private enforcement are likely to be most effective if they take into account the relationship between the unique features of private enforcement and existing elements of competition law systems. 